\title{
Tax topics a trainee chartered accountant should be taught: a survey of perceptions in and outside public practice
}

B Joubert

Department of Taxation

University of Pretoria

\section{R Oberholzer}

Department of Taxation

University of Pretoria
S Coetzee $^{1}$

Department of Accounting University of Pretoria

\begin{abstract}
This paper presents the results of a survey designed to determine what tax topics are important in the educational background of a trainee accountant entering the training environment in South Africa. These topics were then compared to the 2008 tax syllabus prescribed by SAICA and taught at accredited universities in respect of the 2009 Qualifying Examination. The results indicated that the 2008 syllabus is largely meeting the expectations of respondents both in and outside public practice, although there are a number of topics that the syllabus setters and educators should reconsider when next reviewing and updating the 2008 syllabus and as part of the considerations for the new competency framework.
\end{abstract}

\section{Key words}

Chartered accountant TIPP

Survey TOPP

South Africa Training environment

Tax education

Tax knowledge

\section{Introduction}

Numerous articles have been published internationally about the inadequacies of the traditional tax curriculum (Schwartz \& Stout 1987; Boley \& Wilkie 1986; Hite \& Hasseldine 2001:3; Tan \& Veal 2005). It has been noted in particular that the tax curriculum is too technically focused, with students being unable to cope with the changing business environment and the needs of the accounting profession (Tan \& Veal 2005).

The editor (S Coetzee) withdrew all editorial involvement in this article. Prof E Sadler from the University of South Africa acted as editor for this article. 
The rate of change in the business environment and in the needs and expectations of society has been and remains extremely rapid (Koornhof \& Lubbe [s.a.]; Engelbrecht 2005). These changes have led to the accounting profession (including its tax component) extending its role from being a custodian of business information to the interpretation and communication of information. Hence, owing to the changes taking place, it is necessary that the topics specifically included in the syllabus be constantly reviewed (Boley \& Wilkie 1986; Stara, Shoemaker \& Brown 1991; Koornhof \& Lubbe [s.a.]).

In South Africa, the South African Institute of Chartered Accountants (SAICA) is responsible for developing and maintaining the tax syllabus, and owing to developments in the business and legislative field, constantly reviews the situation (SAICA 2007a). A significant component of this review process is the current development of a competency framework for chartered accountants to guide the education and training of future chartered accountants in South Africa (SAICA [s.a.]).

This study could assist SAICA in the development of the competency framework for chartered accountants because it endeavours to determine whether the tax topics being taught at university are adequate and relevant.

The objectives of this study are therefore to:

1 determine what tax topics should be taught in university in the context of what a recent hire (trainee accountant) should know when he or she starts employment and compare this with the 2008 tax syllabus prescribed by SAICA in respect of the 2009 Qualifying Examination (2008 syllabus)

2 determine if there are any differences in the perceptions of the importance of these topics between TIPP $^{2}$ firms or TOPP ${ }^{3}$ organisations.

The remainder of this paper explains the context of the study, reviews relevant literature, outlines the methodology, provides the results of the study and draws conclusions.

\section{Background}

This section provides the background to the study because "such contextual material greatly aids the reader's understanding of papers and aids the transferability of ideas" (Paisey \& Paisey 2004:78). It focuses on the academic and training programmes of a CA(SA) and the training programmes in and outside of public practice.

\subsection{Academic and training programme}

The education (on a full-time basis ${ }^{4}$ ) and training background of a CA(SA) can be summarised as follows:

$\square$ a relevant four-year degree at a SAICA-accredited university

2 TIPP is defined as "training in public practice undertaken in a registered training office (RTO), namely a firm of chartered accountants" (Rogers 1998).

3 TOPP is defined as "training outside of public practice, undertaken at an approved training office (ATO), namely in commerce and industry" (Rogers 1998)

4 Part-time study through a distance education institution is also a possibility. The candidate can then complete the practical training at the same time. Under these circumstances, the training programme is usually extended to five years. Remission of this training period, however, will be granted on attainment of a relevant degree. 
completion of a 36-month training contract in public practice (TIPP) or outside of public practice (TOPP);

$\square$ completion of a postgraduate diploma or specialised course in auditing or financial management

$\square$ successful completion of the two parts of the Qualifying Examination prepared by SAICA and the Independent Regulatory Board for Auditors (IRBA)

$\square$ registration with SAICA after passing the Qualifying Examinations and completing a training contract (SAICA 2007b).

\subsection{Academic programme}

The responsibility for the training and educational requirements of a $\mathrm{CA}(\mathrm{SA})$ is shared between SAICA and the IRBA (Kolitz [s.a.]). SAICA sets and adjudicates the first final qualifying examination (QE 1) and the Part II Examination in Financial Management, for those trainees outside of public practice. IRBA exercises a monitoring role over the SAICA public practice trainee and QE 1 examination processes.

In addition, the IRBA is responsible for setting and marking the Public Practice Examination (Part II - Auditing) for those trainees in public practice (Kolitz [s.a.]).

These examinations are based on a recognised academic programme prescribed by SAICA which forms part of the requirements to become a $\mathrm{CA}(\mathrm{SA})$. According to Botha (2001:46), this programme develops a person's competence to apply the concepts and principles of technical knowledge, skills and professional values in a way that provides a base that is appropriate for further professional development.

Tax forms an integral part of the recognised academic programme. SAICA established a syllabus committee to develop the tax curriculum, which comprises an education committee member (chairperson), academics nominated by accredited educational institutions and targeted members from public practice and commerce and industry. The committee is responsible for developing and revising the syllabus after consultation with overseas institutes of chartered accountants and consultation with educational institutions in South Africa. The approved syllabus is then sent to all educational institutions (SAICA 2008:12).

While SAICA is responsible for defining the tax syllabus, it is not responsible for providing courses or educational material (SAICA 2007a:3); this responsibility is left to the relevant accredited educational institution.

On completion of the academic programme, the trainee accountant enters training either in or outside public practice.

\subsection{Training in public practice (TIPP)}

In order to perform the attest function (i.e. sign an audit report), candidates need to specialise in the audit function. This is achieved when registering for a training contract under the TIPP programme (SAICA 2007c).

Training in accountancy firms in public practice falls broadly into three categories, namely small, medium and large firms, and provides trainees with experience according to the size and client base of such firms (SAICA 2007c).

Small firms offer many services, including tax planning, and trainees working in these firms generally gain experience in a client's entire business and may have the opportunity 
to make significant contributions to that client. Small firms are usually community based and entrepreneurs are their main clients, although local retailers and manufacturers, small to medium-sized companies, close corporations and private individuals may also be clients (SAICA 2007c).

Medium firms have a similar client profile to small firms, their clients ranging from independent businesses to household-name companies covering a wide range of products and service sectors (SAICA 2007c).

Large firms employ the most graduate trainees each year, and training in these firms provides trainees with experience in and knowledge of how businesses operate. Trainees may have exposure to some of the world's best-known companies, across a range of industries. The working environment is extremely team oriented and often specialised (SAICA 2007c).

\subsection{Training outside of public practice (TOPP)}

The TOPP programme was established in 1996 by SAICA following the realisation that the large majority of South Africa's CAs(SA) tended to leave public practice upon qualifying and take up positions in commerce and industry. This often required retraining in financial management and business principles because the traditional training route focused on auditing (SAICA 2007d).

TOPP affords CAs the opportunity to extend their knowledge of various business fields such as risk, financial, corporate governance, internal auditing and operations and management accounting (TippTopp News 2006a:2).

TOPP's primary objectives are to (TippTopp News 2006a:2)

"encourage greater entry into, and upward mobility within the accountancy profession;

$\square$ increase the supply of scarce skills by creating more professional training opportunities for potential CAs(SA); and

$\square$ promote education, training and retention of key accounting professionals in organisations"

TOPP candidates specialise in financial management and not auditing. Trainees are trained to become well-rounded chartered accountants and a major part of their training is focused on financial accounting, management accounting, information and tax (Standard Bank 2007).

For those trainees who qualify as $\mathrm{CAs}(\mathrm{SA})$ in commerce, the exposure and experience they gain through the TOPP programme makes it easy for them to move into other job positions in future years (Accountancy SA 2007).

\subsection{Current tax components of TIPP and TOPP programmes}

The main role of entry-level trainees in public practice is their involvement in performing audits. They will examine, on a test basis, evidence supporting the amounts and disclosures in the financial statements, and in this way contribute towards providing assurance that the financial statements are not materially misstated.

One of the main sections to be tested in an audit is the tax components disclosed in both the statement of comprehensive income (income statement) and the statement of financial 
position (balance sheet). The client will perform the calculations and the trainee will determine if they are reasonable by assessing what income and expenses are deductible for tax purposes.

Chartered accountants and their trainees in public practice are also likely to be involved in advising clients on how to lawfully minimise their tax liabilities through efficient tax planning. They may also be involved in submitting tax returns, giving advice on tax implications, resolving tax problems and generally assisting clients with their personal financial affairs (SAICA 2007e).

Chartered accountants and their trainees who train outside public practice may perform the role of a financial manager or accountant, a treasurer, a company secretary, an internal auditor or a tax specialist (SAICA 2007e). The technical skills in tax that a person involved in the TOPP programme needs to demonstrate include the ability to (SAICA 2006A):

$\square$ extract and analyse income, expenditure and other relevant tax data and perform income tax calculations

$\square$ prepare income tax returns for submission to the South African Revenue Services (SARS) in compliance with the requirements of legislation

$\square$ prepare statutory returns other than income tax returns, in compliance with the requirements of legislation

$\square$ account for all taxes in the accounting records

Individuals training in and outside public practice are expected to have some level of tax knowledge.

\section{Literature review}

There is little formal, peer-reviewed research in the field of tax education in South Africa. Coetzee and Oberholzer (2006) performed an exploratory study to determine the important tax topics that should be taught at university, from the perspective of both TIPP" and TOPP firms. While it was found that the SAICA is largely meeting the tax education needs of both TIPP and TOPP organisations, the findings were limited by the narrow geographical region in which the study was conducted, namely Pretoria, South Africa. The study sought to expand on the study of Coetzee and Oberholzer (2006) by selecting a sample of participants from all SAICA-accredited training firms and organisations in South Africa, and not only in Pretoria.

However, the issue of the tax knowledge of entry-level trainees and what they should or should not be taught has been raised several times in international literature.

The debate over the appropriateness of the tax curriculum started as early as the 1960s in the USA. Gray (1965) surveyed those institutions accredited by the American Association of Collegiate Schools of Business (AACSB) in order to ascertain the content of the first tax course. His findings indicated that tax educators of the era ranked an understanding of the current provisions of the tax law as most important, followed by history and philosophy of the income tax, tax ethics and economic aspects (Gray 1965:205).

A survey by Schwartz and Stout (1987) amongst practitioners and educators discussed the tax educational requirements necessary to prepare an undergraduate accounting major to become an entry-level auditor/accountant in a public accounting firm. Of the respondents, $21 \%$ believed that existing courses did not adequately prepare graduating accounting 
majors in tax, while $67 \%$ believed that these graduates were only marginally prepared. Schwartz and Stout (1987) also found that educators still spent less time on corporate tax than practitioners would have preferred. The research concluded with the suggestion that there were significant differences of opinion between those topics which practitioners require and those that educators felt were important. For any university programme to remain relevant, the content and focus thereof should also be geared towards the needs of students for careers in public accounting and other sectors. This can only be achieved if educators have an in-depth understanding of the needs of practitioners and other organisations (Tan \& Veal 2005).

The results of the study performed by Stara et al. (1991) again highlighted that there are substantial differences in opinion about what tax courses are offered by graduate programmes and what courses are perceived as important by practitioners for individuals who will be required to perform simple or complex tax engagements in the first two years of their professional careers.

In 1999, the American Institute of Certified Public Accountants' tax division task force developed the Model Tax Curriculum (MTC) for implementation in universities, where greater emphasis was placed on business taxes and tax planning. The MTC also covered a broad range of tax concepts, types of taxpayers and the role of tax in business decision making, and suggested that more emphasis should be placed on the differences between financial and tax accounting and that tax research, planning and ethics should be integrated into and emphasised throughout the programme.

Although the vast majority of research in this area has been conducted in the USA, other studies have been performed elsewhere. Craner and Lymer (1999) conducted a postal survey in the UK, where the principal aim of their study was to draw conclusions about the nature of tax education in UK accounting degrees by examining the relationships between some of the characteristics of individual tax courses. The authors concluded that there is a heavy bias towards income tax and corporation tax as the primary two tax topics covered. A low coverage of indirect taxes, local taxes and security taxes was also found. The teaching method of those subjects with the most coverage was a computational approach, whereas a more theoretical approach was adopted for the subjects receiving less coverage.

Miller and Woods (2000) performed an additional study in the UK. The authors sought to compare educators' and employers' perceptions of the knowledge of tax acquired by students at university and the knowledge which employers expected of them. The views differed depending on whether the educators were from "old" (pre-1992) or "new" (post1992) universities. "An appreciation of the general scheme of the UK tax" was ranked as the most important learning outcome by all educators, while the ability to perform tax computations was ranked second by educators in the new universities, while educators from the old universities ranked them eighth. Overall, $40 \%$ of employers indicated that they would have a strong expectation of graduates possessing the ability to perform tax computations, while $87 \%$ of educators deemed this ability to be a key learning outcome. This is another example of accounting education not be meeting practitioners' needs and requirements. Overall, the results of Miller and Woods's (2000) study suggest that there are differences between the old and new universities and also between employers' current expectations of graduates' tax abilities and employers' preferences for tax abilities (Miller \& Woods 2000:223). 
Tan and Veal's (2005) study in New Zealand indicated that educators were of the opinion that graduates need to have a higher level of conceptual knowledge of tax planning, avoidance and evasion, whereas practitioners possibly did not consider conceptual knowledge of these subjects to be that important for new graduates because not all of them ultimately specialise in tax. Although tax educators exposed their students to a wide range of topics, the study found that the subjects were not covered to the extent that practitioners would expect them to be. Tan and Veal's (2005) study only sought respondents' perceptions of the level of knowledge and ability required of accounting graduates who intended working in public practice, and as such, the findings should not be generalisable to other private and public sectors.

More recent research conducted by Jones and Abraham (2007) on accountants in general, highlights the difference in perceptions of practitioners, academics and students, and raises questions about the adequacy of the existing training of accountants. They suggest that it imperative to distinguish what should be of central importance to universities, and whether their primary focus should be on meeting the needs of practitioners by providing training that enables students to adapt easily in the workplace. The authors go on to say that the students' expectations also need to be considered in terms of whether they are able to develop the skills necessary for success by being provided with sufficient information about their future roles (Jones \& Abraham 2007:17).

\section{Methodology}

This empirical research project was a descriptive study of people who, in a training officer's $\mathrm{s}^{5}$ opinion are in the best position to comment on the important tax topics a trainee chartered accountant should be taught. It was based on a communicative method of data collection via a structured, self-administered e-mail questionnaire. To minimise the effect of any bias on the part of the researcher, the study was ex post facto. It was also crosssectional in order to capture the respondents' opinions at a specific point in time.

\subsection{Sampling}

\subsubsection{Target population}

Directing the questionnaire to an informed individual is crucial to the success of survey research because it increases the response rate and ensures the quality of the responses (Benke \& Street 1992). While a training officer is ultimately responsible for the TIPP or TOPP programme and remains accountable to SAICA for the training, development and assessment of trainee accountants (TippTopp News 2006b:8), anecdotal evidence suggests that it is not necessarily the training officer who works with trainee accountants on a dayto-day In this research, training officers were therefore contacted and asked to distribute the survey to the person who, in their opinion, was in the best position to comment on the tax

5 Within the training office, a training officer is appointed by SAICA to facilitate the training programmes for future chartered accountants, and he or she is ultimately responsible for the TOPP or TIPP programme. This training officer must be a member of SAICA and should hold a sufficiently senior position to be able to influence the planning and implementation of a trainee's work experience and study programme. It is the responsibility of training officers to ensure that trainee accountants receive the appropriate training in accordance with SAICA's requirements (SAICA 2006b). 
topics which should be included in a trainee accountant's educational background before he or she enters the training environment. This meant that the questionnaire could be completed by the training officer himself or herself, another partner, a manager or someone else.

The target population was limited to training offices both in public practice (TIPP) and in commerce and industry (TOPP), as registered with SAICA on 11 June 2007.

\subsubsection{Sampling method}

A list of all 902 training offices, registered with SAICA, in South Africa, was obtained from SAICA. The list was stratified between those offices involved in public practice (TIPP), numbering 809 (p), and those involved in commerce and industry (TOPP) numbering 93.

\subsubsection{Sample size}

The sample size for circularisation of offices training in public practice was calculated in accordance with the formula $(\sqrt{p / 20} X 20)$, as devised by Stroker $(1981)$, and resulted in a sample of 128 training offices in public practice. A randomised sample of 128 offices was then extracted from the total 809 offices on the basis of a random number computer selection.

The entire population of training offices in commerce and industry, namely 93, was circularised to allow for more meaningful analysis.

\subsection{Data collection}

\subsubsection{Survey method}

Data were collected via an e-mail survey based on the approach adopted in similar international studies (Boley \& Wilkie 1986; Schwartz \& Stout 1987; Tan \& Veal 2005). The respondents were required to complete a structured, self-administered e-mail questionnaire whose design was based largely on Coetzee and Oberholzer's (2006) study.

Since the response rate to a questionnaire is usually low, a concerted effort was made to increase it by minimising the time required to complete the questionnaire. This included shortening the length of the questions, and ensuring that the instructions were clear and questions unambiguous and meaningful. This was done by conducting pilot testing. The importance of the research was also communicated to the potential respondents in an attempt to improve the response rate. In addition, a second, third and fourth request was sent to the non-respondents.

The tax topics used in the questionnaire were extracted, firstly, by using Coetzee and Oberholzer's (2006) questionnaire; secondly, referring to the various Tax Acts, thirdly, referring to various schedules of the Income Tax Act 58 of 1962, as amended up to 31 December 2006; and finally, consulting two textbooks currently used at university to teach tax topics, namely Income tax in South Africa (Clegg \& Stretch 2007) and Silke on South African income tax (De Koker 2007).

Coetzee and Oberholzer's (2006) questionnaire was used to compile a list of tax topics. The various tax Acts and schedules were then utilised to ensure that all tax topics were included in the list. The textbooks were used to ensure that all the tax topics being taught at 
university were included in the questionnaire and to decide whether any topic should be split into various categories. It was decided that the split of topics would not be feasible and was not necessary to achieve the objective of the study.

Since the SAICA 2008 syllabus is not an exhaustive list of all possible tax topics in South Africa, the questionnaire was not based on it. The questionnaire attempted instead to include all tax topics relevant to the South African environment.

\subsubsection{Measurement}

The questionnaire contained a list of 33 tax topics. The respondents were asked to rate the tax topics as important or not in terms of a trainee chartered accountant entering the training environment. The following Likert scale was used: $1=$ not important; 2 = slightly important; 3 = important; and 4 = very important.

\subsubsection{Pretesting}

A pilot study was conducted by circulating the questionnaire to three full-time academics, with research and practice experience, as well as one audit manager and one audit partner involved in TIPP. In-depth personal interviews were conducted with these respondents to obtain constructive comments that were then used to improve the questionnaire design. The updated questionnaire was then forwarded to the same people for their comments as well as another audit manager and another audit partner involved in public practice and to another two people involved in academia. Telephonic interviews were held with these respondents to obtain their constructive comments, which were used to finalise the questionnaire design.

\subsubsection{Response rate}

The following response rates were achieved: $\quad \underline{n}$

Respondents from training offices in public practice $\quad 41(32 \%)$

Respondents from training offices outside of public practice $\quad 26(28 \%)$

A disappointingly low overall response rate of $30 \%(n=67)$ was achieved, although it was in line with similar studies conducted internationally (Boley \& Wilkie 1986, 36.4\%,; Stara et al. 1991, 22.8\%). This study utilised an electronic mail research instrument in the format of a Microsoft Excel document, in contrast to the international studies, which utilised a postal (mail) research instrument. The response rate in Coetzee and Oberholzer's (2006) study was $38 \%$.

\subsubsection{Limitations of the study}

This study was performed on a sample of training offices in South Africa, and may not be indicative of the opinion of all training offices in South Africa, because a disappointingly low response rate of $30 \%$ was achieved.

\subsection{Data analysis}

Descriptive statistics were generated using Microsoft Excel. Owing to the low response rate, the analysis did not involve overly complex statistical methodology and was confined to simple measures appropriate for rating scale data. 


\section{Results}

\subsection{Respondent profile}

The first part of the questionnaire contained questions on the demographic profile of the respondents, who were, in a training officer's opinion, the people in the best position to comment on the tax knowledge of entry-level trainee accountants. Interestingly the majority of respondents were the training officers themselves (75\%), with some respondents being partners $(4 \%)$, managers $(15 \%)$ or other $(6 \%)$

Most of the respondents $(61 \%)$ were from offices training in public practice. The majority $(73 \%)$ of the respondents from offices training in public practice were from small firms, and $66 \%$ of respondents outside of public practice were in the private sector. The respondents' demographics are illustrated in table 1.

\section{Table 1: Respondents' demographics}

\begin{tabular}{|c|c|c|}
\hline Total population & $\mathbf{n}$ & \% \\
\hline TIPP & 41 & 61 \\
\hline TOPP & 26 & 39 \\
\hline Total & $\mathbf{6 7}$ & $\mathbf{1 0 0}$ \\
\hline
\end{tabular}

\begin{tabular}{|l|c|c|c|c|}
\hline \multirow{2}{*}{ Position in company } & \multicolumn{2}{|c|}{ TIPP } & \multicolumn{2}{c|}{ TOPP } \\
\cline { 2 - 5 } & $\mathbf{n}$ & $\%$ & $\mathbf{n}$ & $\%$ \\
\hline Training officer/staff partner & 33 & 80 & 17 & 65 \\
\hline Partner/director & 2 & 5 & 1 & 4 \\
\hline Manager/supervisor & 4 & 10 & 6 & 23 \\
\hline Other & 2 & 5 & 2 & 8 \\
\hline Total & $\mathbf{4 1}$ & $\mathbf{1 0 0}$ & $\mathbf{2 6}$ & $\mathbf{1 0 0}$ \\
\hline
\end{tabular}

\subsection{Most important topics}

The respondents were asked to rate the tax topics as important or not, in terms of a trainee accountant entering the training environment. The scale had the following response options: 1 = not important; 2 = slightly important; 3 = important; and 4 = very important. In order to determine how important certain tax topics were, a mean score was calculated for each topic (table 2).

The topics with the highest mean score were general tax knowledge $(M=3.84)$, company $\operatorname{tax}(M=3.82)$, value-added tax $(M=3.72)$, employees' tax $(M=3.51)$, individual tax $(M=$ $3.40)$, provisional tax $(M=3.40)$ and fringe benefits $(M=3.40)$. All of these topics were included in the 2008 syllabus. 
Table 2: Importance of tax topics $(n=67)$

\begin{tabular}{|c|c|c|c|c|c|c|c|}
\hline & Tax topics & $1^{*}$ & $2^{*}$ & $3^{*}$ & $4^{*}$ & M & SD \\
\hline & Topics included in the 2008 syllabus & & & & & & \\
\hline 1 & General tax knowledge & - & 2 & 13 & 85 & 3.84 & 0.41 \\
\hline 2 & Company tax & - & 1 & 15 & 84 & 3.82 & 0.42 \\
\hline 3 & Value-added tax & - & 6 & 16 & 78 & 3.72 & 0.57 \\
\hline 4 & Employees' tax & - & 9 & 31 & 60 & 3.51 & 0.66 \\
\hline 5 & Individual tax & - & 12 & 36 & 52 & 3.40 & 0.70 \\
\hline 6 & Provisional tax & 3 & 10 & 30 & 57 & 3.40 & 0.80 \\
\hline 7 & Fringe benefits & 2 & 12 & 31 & 55 & 3.40 & 0.76 \\
\hline 8 & Taxation of close corporations & 3 & 15 & 28 & 54 & 3.33 & 0.84 \\
\hline 9 & Secondary tax on companies (STC) & - & 12 & 57 & 31 & 3.19 & 0.63 \\
\hline 10 & Taxation of small business corporations & 3 & 20 & 34 & 43 & 3.18 & 0.85 \\
\hline 11 & Taxation of trusts & 7 & 21 & 36 & 36 & 3.00 & 0.94 \\
\hline 12 & Taxation of partnerships & 10 & 29 & 21 & 40 & 2.91 & 1.06 \\
\hline 13 & General administration (returns, objections, etc) & 6 & 36 & 43 & 15 & 2.67 & 0.81 \\
\hline 14 & $\begin{array}{l}\text { Tax planning (the structuring of and advice on a } \\
\text { client's tax affairs, etc) }\end{array}$ & 6 & 36 & 43 & 15 & 2.67 & 0.81 \\
\hline 15 & $\begin{array}{l}\text { Corporate rules (company formations and intra- } \\
\text { group transactions) }\end{array}$ & 14 & 22 & 52 & 12 & 2.63 & 0.87 \\
\hline 16 & $\begin{array}{l}\text { Lump-sum benefits from pension, provident and } \\
\text { retirement annuity funds }\end{array}$ & 3 & 40 & 52 & 5 & 2.58 & 0.63 \\
\hline 17 & Donations tax & 7 & 33 & 57 & 3 & 2.55 & 0.68 \\
\hline 18 & Taxation of employment companies & 20 & 37 & 40 & 3 & 2.27 & 0.81 \\
\hline 19 & Taxation of non-resident branch & 18 & 39 & 43 & - & 2.25 & 0.75 \\
\hline 20 & Taxation of share dealers & 24 & 37 & 36 & 3 & 2.18 & 0.83 \\
\hline 21 & Estate duty & 19 & 54 & 21 & 6 & 2.13 & 0.80 \\
\hline 22 & $\begin{array}{l}\text { Taxation of foreign entertainers and } \\
\text { sportspersons }\end{array}$ & 56 & 22 & 22 & - & 1.67 & 0.82 \\
\hline & Topics not included in the 2008 syllabus & & & & & & \\
\hline 1 & $\begin{array}{l}\text { Taxation of recreational clubs and public benefit } \\
\text { organisations }\end{array}$ & 20 & 34 & 21 & 25 & 2.52 & 1.08 \\
\hline 2 & Taxation of farming activities & 27 & 27 & 24 & 22 & 2.46 & 1.12 \\
\hline 3 & $\begin{array}{l}\text { Tax research (researching case law and } \\
\text { legislation, etc.) }\end{array}$ & 18 & 30 & 43 & 9 & 2.43 & 0.89 \\
\hline 4 & International tax & 16 & 54 & 27 & 3 & 2.16 & 0.73 \\
\hline 5 & Customs and excise duties & 18 & 57 & 24 & 1 & 2.09 & 0.69 \\
\hline 6 & Transfer and stamp duties & 15 & 69 & 13 & 3 & 2.04 & 0.64 \\
\hline 7 & Taxation of co-operatives & 39 & 36 & 25 & - & 1.87 & 0.80 \\
\hline 8 & Taxation of ship and aircraft owners/charters & 46 & 28 & 26 & - & 1.76 & 0.82 \\
\hline 9 & Taxation of film owners & 55 & 42 & 3 & - & 1.48 & 0.56 \\
\hline 10 & Taxation of mines & 75 & 20 & 6 & 1 & 1.34 & 0.66 \\
\hline 11 & Taxation of long-term insurers & 79 & 16 & 5 & - & 1.25 & 0.53 \\
\hline${ }^{*}-1$ & ot important; 2 = slightly important; 3 = impor & & & & & & \\
\hline $\mathrm{M}=$ & ean & & & & & & \\
\hline & & & & & & & \\
\hline
\end{tabular}


The least important topics included taxation of co-operatives, taxation of ship and aircraft owners/charters, taxation of foreign entertainers and sportspersons, taxation of film owners, taxation of mines, and taxation of long-term insurers, with more than $50 \%$ of the respondents in each instance stating that the topic was not important, and consequently resulting in a mean of less than 2 (slightly important). Most of these topics were not included in the 2008 SAICA tax syllabus. The exception was the taxation of foreign entertainers and sportspersons. This topic was included in the tax syllabus for the first time in the 2008 syllabus. The inclusion thereof should perhaps be reconsidered.

A further topic that was included in the 2008 SAICA syllabus and received little support from the respondents was estate duty. Several topics currently not included in the SAICA syllabus such as the corporate rules, taxation of recreational clubs and public benefit organisations, farming activities, tax research and international tax ranked higher than estate duty. Estate duty was also ranked the least important in the study of Coetzee and Oberholzer (2006) and that of Boley and Wilkie (1986). Hence the inclusion of estate duty in the tax syllabus possibly merits reconsideration.

Since almost two-thirds of the respondents were from public practice, the overall responses may have been biased towards this respondent group's perception. The next section will investigate whether any specific differences existed between respondents from the different training programmes.

\subsection{TIPPS versus TOPPS training}

When analysing the differences between offices using TIPPS and TOPPS, it should be noted, as indicated in table 3 , that general tax knowledge, company tax, and value-added tax ranked as the three most important topics for both training schemes. This supports the previous findings for the respondent group as a whole.

The least important topics continued to include taxation of co-operatives, international tax, customs and excise duties, taxation of foreign entertainers and sport persons, taxation of ship and aircraft owners/charters, taxation of film owners, taxation of mines, and taxation of long-term insurers, all of which had a mean of less than 2 (slightly important) for both TIPPS and TOPPS offices.

The first major difference between the two different training offices, as indicated in table 3 , was the ranking of individual tax, whereby TIPP firms ranked it at number 4 , versus a ranking of 8 by TOPP organisations. Other major differences between the two different training offices regarding the importance of topics currently included in the SAICA syllabus included ranking of the following:

$\square$ Secondary tax on companies was ranked as number 6 for TOPP with a mean of 3.35, and only as number 12 for TIPP offices with a mean of 3.10

$\square$ TOPP organisations ranked corporate rules at number 9 with a mean of 3.08, while TIPP firms ranked it number 20 with a mean of 2.34 .

The following differences were evident from table 3 with regard to topics currently excluded from the SAICA syllabus:

International tax was ranked at number 15 for TOPP offices with a mean of 1.88 , and only at 27 for TIPP offices, with a mean of 2.62.Taxation of recreational clubs and public benefit organisations was ranked at number 13 for TIPP, with a mean of 2.95, but only at number 27 for TOPP, with a mean of 1.85 . 
$\square$ TIPP firms ranked farming activities as number 14 , with a mean of 2.73 , and TOPP firms at number 25 , with a mean of 2.04 .

$\square$ TIPP firms ranked customs and excise as number 28 , with a mean of 1.83 , and TOPP firms at 18 , with a mean of 2.50 .

A surprising fact that emerged from the above was that TIPP firms ranked the taxation of recreational clubs and public benefit organisations, as well as farming activities, which are not part of the SAICA syllabus, as more important than the following topics currently included in the SAICA syllabus: donations tax, lump-sum benefits and estate duty.

A final interesting finding was that TOPP organisations ranked tax research (researching case law and legislation) as number 14, with a mean of 2.73 , whereas TIPP firms ranked it as number 22 , with a mean of 2.24. The training firms therefore appear to attach reasonable importance to the skill of being able to research case law and legislation.

Taking the above into account it might be worthwhile for SAICA to re-evaluate the inclusion and exclusion of certain topics from the syllabus.

Table 3: Importance of tax topics: TIPP versus TOPP (in order of importance)

\begin{tabular}{|c|c|c|c|c|c|c|c|c|}
\hline & TIPP firms $(n=41)$ & M & SD & SAICA & $\begin{array}{l}\text { TOPP organisations } \\
(n=26)\end{array}$ & M & SD & SAICA \\
\hline 1 & General tax knowledge & 3.90 & 0.37 & $\sqrt{ }$ & Company tax & 3.88 & 0.33 & $\sqrt{ }$ \\
\hline 2 & Company tax & 3.78 & 0.47 & $\sqrt{ }$ & Value-added tax & 3.77 & 0.43 & $\sqrt{ }$ \\
\hline 3 & Value-added tax & 3.68 & 0.65 & $\sqrt{ }$ & General tax knowledge & 3.73 & 0.45 & $\sqrt{ }$ \\
\hline 4 & Individual tax & 3.59 & 0.63 & $\sqrt{ }$ & Employees' tax & 3.46 & 0.58 & $\sqrt{ }$ \\
\hline 5 & Employees' tax & 3.54 & 0.71 & $\sqrt{ }$ & Provisional tax & 3.46 & 0.65 & $\sqrt{ }$ \\
\hline 6 & Taxation of close corporations & 3.54 & 0.81 & $\sqrt{ }$ & $\begin{array}{l}\text { Secondary tax on companies } \\
\text { (STC) }\end{array}$ & 3.35 & 0.56 & $\sqrt{ }$ \\
\hline 7 & Fringe benefits & 3.49 & 0.75 & $\sqrt{ }$ & Fringe benefits & 3.27 & 0.78 & $\sqrt{ }$ \\
\hline 8 & $\begin{array}{l}\text { Taxation of small business } \\
\text { corporations }\end{array}$ & 3.46 & 0.78 & $\sqrt{ }$ & Individual tax & 3.12 & 0.71 & $\sqrt{ }$ \\
\hline 9 & Provisional tax & 3.37 & 0.89 & $\sqrt{ }$ & $\begin{array}{l}\text { Corporate rules (company } \\
\text { formations and intra-group } \\
\text { transactions) }\end{array}$ & 3.08 & 0.63 & $\sqrt{ }$ \\
\hline 10 & Taxation of trusts & 3.32 & 0.85 & $\sqrt{ }$ & Taxation of close corporations & 3.00 & 0.80 & $\sqrt{ }$ \\
\hline 11 & Taxation of partnerships & 3.22 & 0.94 & $\sqrt{ }$ & $\begin{array}{l}\text { General administration (returns, } \\
\text { objections, etc.) }\end{array}$ & 2.92 & 0.74 & $\sqrt{ }$ \\
\hline 12 & $\begin{array}{l}\text { Secondary tax on companies } \\
\text { (STC) }\end{array}$ & 3.10 & 0.66 & $\sqrt{ }$ & $\begin{array}{l}\text { Tax planning (the structuring of } \\
\text { and advice on a client's tax } \\
\text { affairs, etc.) }\end{array}$ & 2.85 & 0.67 & $\sqrt{ }$ \\
\hline 13 & $\begin{array}{l}\text { Taxation of recreational clubs } \\
\text { and public benefit organisations }\end{array}$ & 2.95 & 0.95 & $x$ & $\begin{array}{l}\text { Taxation of small business } \\
\text { corporations }\end{array}$ & 2.73 & 0.78 & $\sqrt{ }$ \\
\hline 14 & Taxation of farming activities & 2.73 & 1.10 & $x$ & $\begin{array}{l}\text { Tax research (researching case } \\
\text { law and legislation, etc.) }\end{array}$ & 2.73 & 0.87 & $x$ \\
\hline 15 & Donations tax & 2.63 & 0.70 & $\sqrt{ }$ & International tax & 2.62 & 0.75 & $x$ \\
\hline 16 & $\begin{array}{l}\text { Lump-sum benefits from } \\
\text { pension, provident and } \\
\text { retirement annuity funds }\end{array}$ & 2.59 & 0.67 & $\sqrt{ }$ & $\begin{array}{l}\text { Lump-sum benefits from } \\
\text { pension, provident and } \\
\text { retirement annuity funds }\end{array}$ & 2.58 & 0.58 & $\sqrt{ }$ \\
\hline 17 & $\begin{array}{l}\text { Tax planning (the structuring of } \\
\text { and advice on a client's tax } \\
\text { affairs, etc.) }\end{array}$ & 2.56 & 0.87 & $\sqrt{ }$ & Taxation of trusts & 2.50 & 0.86 & $\sqrt{ }$ \\
\hline 18 & $\begin{array}{l}\text { General administration (returns, } \\
\text { objections, etc.) }\end{array}$ & 2.51 & 0.81 & $\sqrt{ }$ & Customs and excise duties & 2.50 & 0.71 & $x$ \\
\hline 19 & $\begin{array}{l}\text { Taxation of employment } \\
\text { companies }\end{array}$ & 2.39 & 0.80 & $\sqrt{ }$ & Taxation of partnerships & 2.42 & 1.06 & $\sqrt{ }$ \\
\hline
\end{tabular}


Tax topics a trainee CA should be taught: a survey of perceptions in and outside public practice

\begin{tabular}{|c|c|c|c|c|c|c|c|c|}
\hline & TIPP firms $(n=41)$ & M & SD & SAICA & $\begin{array}{l}\text { TOPP organisations } \\
(n=26)\end{array}$ & M & SD & SAICA \\
\hline 20 & $\begin{array}{l}\text { Corporate rules (company } \\
\text { formations and intra-group } \\
\text { transactions) }\end{array}$ & 2.34 & 0.88 & $\sqrt{ }$ & Donations tax & 2.42 & 0.64 & $\sqrt{ }$ \\
\hline 21 & Estate duty & 2.24 & 0.83 & $\sqrt{ }$ & Taxation of non-resident branch & 2.38 & 0.70 & $\sqrt{ }$ \\
\hline 22 & $\begin{array}{l}\text { Tax research (researching case } \\
\text { law and legislation, etc.) }\end{array}$ & 2.24 & 0.86 & $x$ & Taxation of share dealers & 2.23 & 0.86 & $\sqrt{ }$ \\
\hline 23 & Taxation of non-resident branch & 2.17 & 0.77 & $\sqrt{ }$ & $\begin{array}{l}\text { Taxation of employment } \\
\text { companies }\end{array}$ & 2.08 & 0.80 & $\sqrt{ }$ \\
\hline 24 & Taxation of share dealers & 2.15 & 0.82 & $\sqrt{ }$ & Transfer and stamp duties & 2.08 & 0.56 & $x$ \\
\hline 25 & Transfer and stamp duties & 2.02 & 0.69 & $x$ & Taxation of farming activities & 2.04 & 1.04 & $x$ \\
\hline 26 & Taxation of co-operatives & 1.93 & 0.85 & $x$ & Estate duty & 1.96 & 0.72 & $\sqrt{ }$ \\
\hline 27 & International tax & 1.88 & 0.56 & $x$ & $\begin{array}{l}\text { Taxation of recreational clubs } \\
\text { and public benefit organisations }\end{array}$ & 1.85 & 0.92 & $x$ \\
\hline 28 & Customs and excise duties & 1.83 & 0.54 & $x$ & Taxation of co-operatives & 1.77 & 0.71 & $x$ \\
\hline 29 & $\begin{array}{l}\text { Taxation of foreign entertainers } \\
\text { and sportspersons }\end{array}$ & 1.80 & 0.87 & $\sqrt{ }$ & $\begin{array}{l}\text { Taxation of ship and aircraft } \\
\text { owners/charters }\end{array}$ & 1.69 & 0.74 & $x$ \\
\hline 30 & $\begin{array}{l}\text { Taxation of ship and aircraft } \\
\text { owners/charters }\end{array}$ & 1.80 & 0.87 & $x$ & Taxation of mines & 1.58 & 0.81 & $x$ \\
\hline 31 & Taxation of film owners & 1.46 & 0.55 & $x$ & Taxation of film owners & 1.50 & 0.58 & $x$ \\
\hline 32 & Taxation of mines & 1.20 & 0.51 & $x$ & Taxation of long-term insurers & 1.46 & 0.65 & $x$ \\
\hline 33 & Taxation of long-term insurers & 1.12 & 0.40 & $x$ & $\begin{array}{l}\text { Taxation of foreign entertainers } \\
\text { and sportspersons }\end{array}$ & 1.46 & 0.71 & $\sqrt{ }$ \\
\hline \multicolumn{9}{|c|}{ Scale values range from 4 ("very important") to 1 ("not important") } \\
\hline \multicolumn{9}{|c|}{$M=$ Mean } \\
\hline \multicolumn{9}{|c|}{ SD = Standard deviation } \\
\hline \multicolumn{9}{|c|}{ SAICA = Included in 2008 syllabus $($ Yes $=\sqrt{ }$ and No $=x)$} \\
\hline
\end{tabular}

\section{Conclusion}

Botha (2001) suggested that the education system may not necessarily be producing competent chartered accountants. In addition, foreign literature (Boley \& Wilkie 1986; Schwartz \& Stout 1987; Stara et al. 1991; Miller \& Woods 2000; Tan \& Veal 2005) reported that tax education programmes are not adequately meeting the needs of practitioners. These findings, supplemented by the lack of reported studies on tax education in South Africa, provided the incentive for this research. The study therefore attempted to determine what tax topics are important in the educational background of a trainee accountant entering the training environment and to then compare these findings with the 2008 SAICA tax syllabus.

SAICA appears largely to be meeting the requirements for trainee accountants entering both the TIPP and TOPP environments. The inclusion of certain topics, however, could merit reconsideration.

In terms of the different training environments (TIPP and TOPP), TOPP organisations ranked customs and excise quite highly, while TIPP firms ranked the taxation of recreational clubs and public benefit organisations highly. SAICA could consider including these topics in the syllabus. The findings suggest that a generalised tax syllabus for training chartered accountant for the TIPP and TOPP programme may no longer be entirely appropriate. 
When interpreting the results, one should bear in mind that the response rate was disappointingly low, In addition, because $73 \%$ of TIPP respondents were from small firms the results of this study may not be generalisable to the entire training environment. Also, large offices training in public practice generally have dedicated tax departments and therefore do not always require trainees to have an in-depth knowledge of tax subjects. This subdivision of firms and organisations within the TIPP and TOPP programmes could provide interesting avenues for future research. This study, however, does cover a new area of research that might be valuable to the different role players involved in the evaluation and revision of the 2008 SAICA syllabus, as well as in the development of the new competency-based framework for the education and training of chartered accountants.

\section{Bibliography}

Accountancy SA. 2007. Leading corporations see value in alternative chartered accountancy training programme. Accountancy SA, May:39.

Benke, R.L. Jr. \& Street, D.L. 1992. Accounting education research methodology. Journal of Accounting Education, 1(1):33-45.

Boley, R. \& Wilkie, P.J. 1986. Practitioners' view of the common body of tax knowledge for persons entering public accounting. Journal of the American Taxation Association, 8:80-97.

Botha, W.J.J. 2001. Pre-qualification education of registered accountants and auditors in South Africa: perspectives on whether the education process is normatively justifiable. Meditari Accountancy Research, 9:33-59.

Clegg, D. \& Stretch, R. 2007. Income tax in South Africa. Durban: LexisNexis Butterworths.

Coetzee, S. \& Oberholzer, R. 2006. The tax knowledge of South African trainee accountants: a survey of training officers' perceptions. Paper presented at the World Congress of Accounting Educators, Istanbul, Turkey, November..

Craner, J. \& Lymer, A. 1999. Tax education in the UK: a survey of tax courses in undergraduate accounting degrees. Journal of Accounting Education, 8(2):127-156.

De Koker, A.P. 2007. Silke on South African income tax. Durban: LexisNexis Butterworths.

Engelbrecht, E. 2005. Adapting to changing expectations: post-graduate students' experience of an e-learning tax program. Computers and Education, 45(2):217-229.

Gray, O.L. 1965. Opinions of tax professors on tax courses: a survey summary. The Accounting Review, 40(1):204-211.

Hite, P. \& Hasseldine, J. 2001 A primer on tax education in the United States of America. Journal of Accounting Education, 10(1):3-13.

Jones, G. \& Abraham, A. 2007. Education implications of the changing role of accountants: perceptions of practitioners, academics and students. University of Wollongong, New South Wales, Australia.

Kolitz, D.L. [s.a.]. The impact of the introductory accounting course on the attraction and retention of high quality students to professional accountancy studies. [Online] 
Available from: http://web.wits.ac.za/NR/rdonlyres/F66DE1CA-AEF0-48FB-9CC6A53C30F5F625/0/DKIntro_Accounting_SAICA.pdf. Accessed: 7 May 2007.

Koornhof, C. \& Lubbe, D. [s.a.]. The expectations and experiences of trainees, training officers and the secretariate of SAICA with regard to the training of accountants in South Africa. [Online] Available from: https://www.saica.co.za/documents/ResearchProject.pdf. Accessed: 7 May 2007.

Miller, A.M. \& Woods, C.M. 2000. Undergraduate tax education: a comparison of educators' and employers' perceptions in the UK. Journal of Accounting Education, $9(3): 223-241$.

Paisey, C. \& Paisey, N.J. 2004. An analysis of accounting education research in accounting education: an international journal - 1992-2001, Accounting Education, 13(1):69.

Rogers, R. 1998. TIPP or TOPP? That is the question. [Online] available from:

http://www.accountancysa.org.za/archives/1998/1998Aug/students/tipp.htm. Accessed: 7 May 2007.

SAICA, vide South African Institute of Chartered Accountants.

Schwartz, B.N. \& Stout, D.E. 1987. A comparison of practitioner and educator opinions on tax education requirements for undergraduate accounting majors. Issues in Accounting Education, 2:112-126.

South African Institute of Chartered Accountants. [s.a.]. A competency framework for newly qualified chartered accountants. [Online] Available from: https://www.saica.co.za. Accessed: 19 June 2008.

South African Institute of Chartered Accountants. 2006a. Training outside of public practice: technical and professional skills requirements: effective in respect of trainees entering into training contracts for the first time on or after 1 January 2006. [Online] Available from: https://www.saica.co.za. Accessed: 7 May 2007.

South African Institute of Chartered Accountants. 2006b. Training general information. [Online] Available from: https://www.saica.co.za. Accessed: 7 May 2007.

South African Institute of Chartered Accountants. 2007a. Education unit terms of reference. [Online] Available from: https://www.saica.co.za. Accessed: 18 June 2008.

South African Institute of Chartered Accountants. 2007b. Become hot property! Start a career in chartered accountancy. [Online] Available from: https://www.saica.co.za. Accessed: 7 May 2007.

South African Institute of Chartered Accountants. 2007c. TIPP. [Online] Available from: https://www.saica.co.za. Accessed: 7 May 2007.

South African Institute of Chartered Accountants. 2007d. TOPP. [Online] Available from: https://www.saica.co.za. Accessed: 7 May 2007.

South African Institute of Chartered Accountants. 2007e. What CAs do. [Online] Available from: https://www.saica.co.za. Accessed: 7 May 2007.

South African Institute of Chartered Accountants. 2008. Education: QE syllabi: introduction.

Standard Bank (2007). Career opportunities - TOPP. [Online]. Available from: www.standardbank.co.za. Accessed: 7 May 2007. 
Stara, N., Shoemaker, P. \& Brown, J. 1991. The curriculum required to develop a tax specialist: a comparison of practitioner opinions with current programs. Journal of Accounting Education, 9:79-104.

Stroker D.J. 1981. Steekproefneming in die praktyk. Prof Honorer Lesing, UP Nuwe Reeks, $\mathrm{Nr}$ 178. (Sampling in practice. Prof. Honoury Lecture, UP New Series, No. 178). Pretoria: UP Printers.

Tan, L.M. \& Veal, J. 2005. Tax knowledge for undergraduate accounting majors: conceptual v. technical. eJournal of Tax Research.

TippTopp News. 2006a. Corporate training programme relaunched as an alternative route to skills development, (1), December:2

TippTopp News. 2006b. Review of training officer requirements, (1), December:8. 